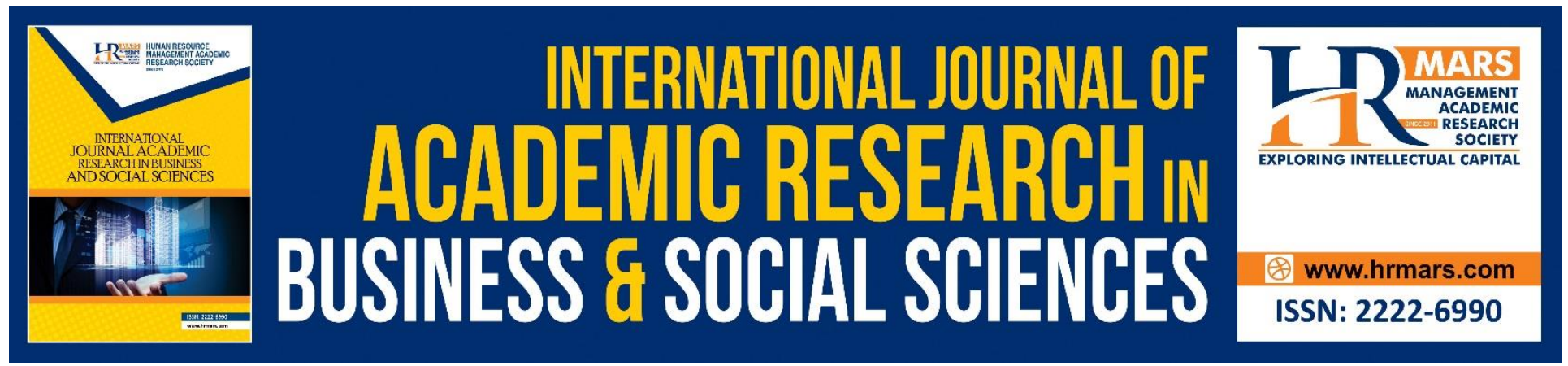

\title{
The Development of Whipping Punishment in the State of Kelantan: Historical Exploration and Recent Implementation in the Shariah Jurisdiction
}

Faisal Bin Husen Ismail \& Jasni Bin Sulong

To Link this Article: http://dx.doi.org/10.6007/IJARBSS/v8-i9/4663

DOI: $10.6007 /$ IJARBSS/v8-i9/4663

Received: 22 August 2018, Revised: 16 Sept 2018, Accepted: 29 Sept 2018

Published Online: 16 October 2018

In-Text Citation: (Ismail \& Sulong, 2018)

To Cite this Article: Ismail, F. B. H., \& Sulong, J. Bin. (2018). The Development of Whipping Punishment in the State of Kelantan: Historical Exploration and Recent Implementation in the Shariah Jurisdiction.

International Journal of Academic Research in Business and Social Sciences, 8(9), 896-908.

Copyright: (c) 2018 The Author(s)

Published by Human Resource Management Academic Research Society (www.hrmars.com)

This article is published under the Creative Commons Attribution (CC BY 4.0) license. Anyone may reproduce, distribute, translate and create derivative works of this article (for both commercial and non-commercial purposes), subject to full attribution to the original publication and authors. The full terms of this license may be seen at: http://creativecommons.org/licences/by/4.0/legalcode

Vol. 8, No. 9, September 2018, Pg. 896 - 908

Full Terms \& Conditions of access and use can be found at http://hrmars.com/index.php/pages/detail/publication-ethics 


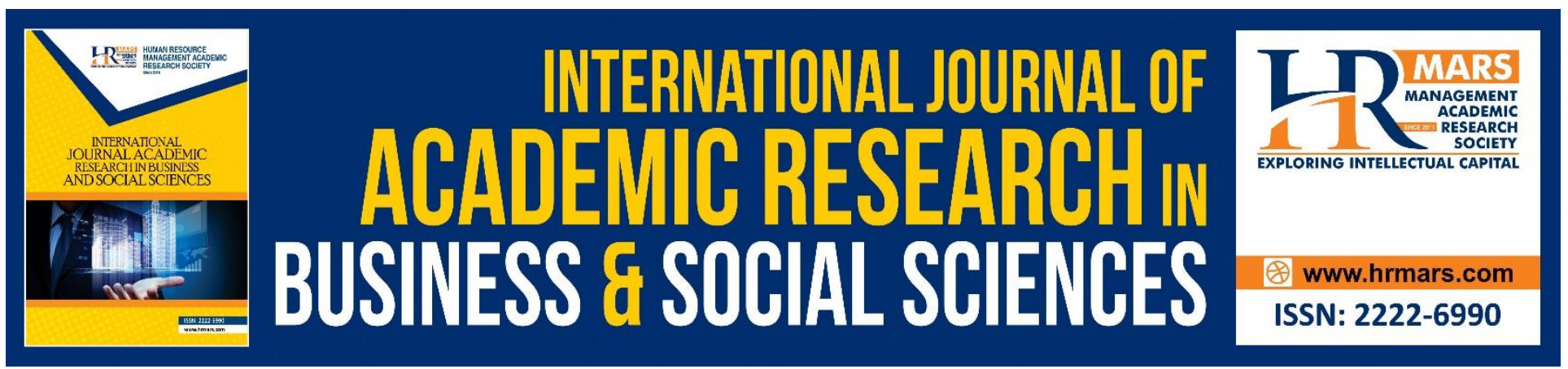

\title{
The Development of Whipping Punishment in the State of Kelantan: Historical Exploration and Recent Implementation in the Shariah Jurisdiction
}

\author{
Faisal Bin Husen Ismail \& Jasni Bin Sulong \\ Universiti Sains Malaysia
}

\begin{abstract}
Whipping is a part of hudud punishment in the Islamic criminal law, for the offence of adultery, accusing of adultery and intoxicating liquor. In recent progress, whipping sentence in the Shariah Court has attract intention of public as well as the Federal Government when the State of Kelantan has tabled a regulation to increase the amount of whipping from six stroke to hundred and to execute the law before the public. The issue arise as the additional volume has contradict to the jurisdiction that was given by the Federal Constitution. It also against the rule that was provided in the Ninth Schedule of the Second List and the Shariah Court Jurisdiction Act 1965. The study will be conducted in a qualitative way by refering to books, manuscripts, journals, law reports and interview. Meanwhile, the method of investigation is using a content analysis by studying every document that related to the topic. It is a research technique used to make replicable and valid inferences by interpreting and coding textual material of the said subject matter. The research found out that the jurisdiction of shariah court on whipping was so far left behind compared to civil court. The Federal Government should accept proposals for renewal by the state of Kelantan. In the end, the power given is for the benefit of the implementation of the shariah law in Kelantan and can be expanded to the whole country.
\end{abstract}

Keywords: Islamic criminal law, Shariah Court, State of Kelantan, Whipping sentence, Shariah offence.

\section{INTRODUCTION}

In recent, the implementation of the High Shariah Court of Terengganu on whipping punishment before the crowd for lesbians has attracted debates (Berita Harian, 5/9/2018). Many see the sanction as humiliating, cruel, improper and not in line with the Islamic wisdom. Many countries abolished the sanction and some countries acknowledge that whipping is a rare punishment (Durnian, 2017) even though it has a long history as an instrument of social control. According to Baldwin (1899), there has never been a time during years ago when whipping was not a mode of criminal punishment. However in recent development, whipping punishment has slowly been removed where penalty shifted more 
on physical deprivation than physical harm. Despite avoiding of physical injury, some scholars still recognize its suitability and appropriateness for certain offences (Durrant, 2008).

On the other hand in the Islamic criminal law, the scholars satisfied that the sanction always practical and realistic to be enforced. In this case, Mohd Shariff et. al (2012) argue that the refusal of some researchers on the sanction merely initiated from misconception that the sanction is barbaric and impractical. In Pakistan (1996), even though the civil law has abolished whipping sentence but in the jurisdiction of Shariah law, the sanction is remained relevant under the hudud laws. Similarly in Malaysia especially in Kelantan, the whipping sanction has long been in existence in the ruling but many do not realize it. Therefore the study is essential to correct the misconception and expose the existence as well as development of the sanction amidst its disparity and uniqueness compared to civil whipping in order to educate the public on this issue.

Historically, the current practice of whipping in Malaysia is a remnant of British colonial regulations dating back to the late 19th century (Amnesty International, 2010). Since the 1990s in the Civil law, the range of offences subject to criminal caning has widened to certain forms of white-collar crime (1994) as well as for immigration offences $(1996,2002)$. Meanwhile the punishment in the Shariah matters remain unchange but with modification in the procedure. Thus, this study has been conducted to discuss about the progress on the whipping punishment in State of Kelantan since the Sultanate era till colonializations and after independence. The aim is to understand the wisdom of whipping execution that became a challenge for Muslims nowadays in implementing shariah law in Malaysia.

Therefore, in order to provide fair discussion on the issue, this paper will investigate the progress of executing whipping punishment in the State of Kelantan as well as in the other states in Malaysia. The selection of the State of Kelantan is special because of the historical records of the Islamic execution site. Historically, Kelantan before the British colonization has emerged as Islamic state where the Islamic law has been implemented which contains hudud, qisas and takzir. However, the arrival of the British and the post-independence effect has caused the jurisdiction of shariahbased penalty getting narrower and becoming more restricted. The jurisdiction is only relates on state power which limited in crime that related to faith and personal matters only.

\section{LITERATURE ON ISLAMIC WHIPPING PUNISHMENT}

Generally, the classic figh does not mention in detail about whipping description. Therefore, Muslim scholars have views on its procedures and substances. Al-Mawardi (1966) has discussed that the definition of whipping in the ruling to hit with a whip (sawt). It is as a kind of twigs of wood which is niether too new nor too old with a simple size. Qudāmah (1980) states that the cane is not too strong and not too weak.

The whipping punishment under shariah is imposed on criminal offenders that is under hudud offences and takzir. Al-Mawardi (1966) defined the offence is the conduct that was done against the Islamic law or breaking prohibitions of God. Thus, the offender will be punished by whipping in order to penal for violation of the law. Basically, there are differences in the number of whipping penalty based on severeness of the wrong doing. In Islamic criminal law, punishment of whipping is provided towards certain types of hudud offences such as illegal intercourse for couples who are not married (adultery muhsan) (Zaydan, 1993), sexual defamatory (qazaf) (Q24: 2), drinking alcohol (syurb) (Q24: 
4) and gambling (maysir) (Abu Daud, 2009). While takzir offences can also be punished to whipping such as stealing (Al-Kasani, 1986) and other hudud offences that does not have sufficient evidence (Al-Mawardi, 1966). As the punishment of hudud is harder than takzir, the whipping number for the former is more than the latter, fixed and mandatory that is 40 strokes for intoxicating liquor, 80 strokes for qazaf and 100 strokes for adultery among bachelors. However, the number of stroke is flexible for the takzir offences which is under the privilege of Islamic judges. In a meantime, the sum can be less or more from hudud punishment depending on finding and context of cases (Audah, 1963).

The procedure of whipping punishment is by hitting on certain parts of the body with certain tools such as rattan on medium strength (Qudāmah, 1980). The rattan (al-jild) is one form of substance using while beating ( $a l-d a r b)$ on the offender body during the execution. In the Quran, the word al-jild is used for the serious offense that is adultery for bachelors (Q24: 2) and committing qazaf (Q24: 4). Al-Bukhari $(1400 \mathrm{H})$ also used the word al-jild for those hudud offences. While the term al-darb in Quran is for a lighter punishment such as in matrimonial offences, for instance of disobedience wife (nusyuz) (Q4:34) where husbands are allowed to darb (beat) his wife with no extreme. Similarly in the case of child who refuses to perform prayer where the Prophet Muhammad pbuh used the word al-darb (Ibn Majah, 2007). However, narration of Al-Tirmizi (2000) seems to apply al-darb for severe punishment such as adultery offences. The Hadith states that the whipping penalty for adulterers are darb for hundred times and expulsion for a year. Nevertheless the contradiction does not distract the intent of punishment for adulterers and disobedient child, whereby al-darb will be used according to the context intended. As agreed upon by al-Ramli and alBahnasi that al-darb is one of the forms of whipping and both of them argued that the term is more suitable for takzir punishment. While al-jild is a severe whipping that should applied for hudud offences due to the context that were used in the Quran and hadith (Al-Ramli, 1968).

In term of uniqueness of the whipping sanction, the punishment in Islam does not really hurt as much as in civil law (Durnian, 2017; Baldwin, 1899). According to Mohd Shariff et. al. (2012), the shot is not so painful for the skin because the stroke method is different. The stroke made does not exceed the shoulder level of the shoulder striker. The principle of the sanction is to ensure that the objectives of punishment, reform and deterrent are achieved without causing unnecessary injury to the convict (Yaacob, 1996). Even the consistency of research findings demonstrating that physical punishment predicts negative developmental outcomes (Durrant, 2008), Islamic law look it in a different way. The severe sanction is fit for for the heinous crime and the same time will reduce the crime. For instance in Saudi Arabia, the harsh punishment has put the crime index to be relatively low compared to other countries that does not apply the law (Ali Mohamed, 2012). Under the Shariah law, the whipping sentence apply to both male and female offenders where all offenders shall suffer the same modes of sentencing when they have committed any crime. Since 2009, the whipping sentence to Kartika Seri Dewi Sukarno and Noorazah Baharuddin for consuming intoxicating beer and three other female offenders for sexual intercourse out of wedlock has shown court fairness in imposing this sentence (Y. B. Othman, Joni, \& Mahat, 2011). 
INTERNATIONAL JOURNAL OF ACADEMIC RESEARCH IN BUSINESS AND SOCIAL SCIENCES

Vol. 8, No. 9, Sept. 2018, E-ISSN: 2222-6990 @ 2018 HRMARS

\section{Administration of Shariah Law in Kelantan}

In Malaysia, Muslim personal matters as well as the administration of Islamic institution in each state are under the jurisdiction of state (Ismail, 2014). The jurisdiction given by the Second List of the Ninth Schedule of the Federal Constitution which in authority for person who profess Islam as his faith. Thus, the shariah law will be applied in their family affairs, beliefs and moral values (Ibrahim, 1994) which lies under the shariah court. However in other matters, the jurisdiction of civil court is preferred and more exclusive than the Shariah Court (Aziz, 2007); (Kamaruddin, 1989). The provision of Islamic criminal law are provided in the Shariah Criminal Code Enactment (EKJS) which the enforcement can only be enforced on Muslims only (Section 3 Enactment 2 Syariah Criminal Code Enactment Kelantan 1985).

Historically, the implementation of Islamic criminal law have been enforced since 1754 in Kelantan. In the Qanun of Customary and Tahafus Kelantan 1754, some criminal offenses have been highlighted in the Qanun such as violence, kidnapping, stealing, having mistress and assassinating (Ahmad, 1989). The Qanun also provided penalties for offenses where money or gold were among penalizing method (Ibid.). However during natural disaster in Kelantan, punishment for stealing has been postponed due to flood disasters which destroyed many plants and crops. The act to suspend the law has been decided based on the decision of Caliph Umar bin al-Khattab when the country is hit by drought which caused starvation and poor (Qudāmah, 1980).

However during British colonial epoch, which took place after the British-Siamese treaty in the year 1909, the administration of Islamic criminal law has been restrained (Su-Ming, 1965). The applicable law for Muslim is only related to morality, faith and marital such as marriage and divorce. Meanwhile the law for stealing, robbery or assassinating were under the authority of the British that falls under the jurisdiction of civil court. The applicable law for Muslim has been improved after independence through the Kelantan Council of Religion and Malay Custom Enacment 1966. The statute has underlined a clearer provision pertaining to crimes which were listed in the part IV of the enactment. There were 17 offences in the enactment such as not attend Friday prayer, intoxicating liquor, food in Ramadzan, improper retention of fund, wilful neglect of statutory duty, breach of secrecy, unlawful mosque, religious teaching, contradictory doctrine, printing, sale, or possession of prohibited publication, misuse of Quran, contempts of religious or religion, non-payment of zakat or fitrah, incitement to neglect religious duty and attempts and abetments. ${ }^{1}$ However all of the listed offences have no penalty in the form of whipping punishment, except with fine not exceeding $\$ 1000$ and imprisonment not exceeding six months or or with combination thereof. ${ }^{2}$ Those provision were in line with the jurisdiction given by the Muslim Court (Criminal Jurisdiction) Act 1965 (Act 355).

In 1984, the Act has been revised which improved the criminal jurisdiction that is, imprisonment for a term not exceeding three years or with any fine not exceeding five thousand ringgit or with whipping not exceeding six strokes or with any combination thereof. As consequence

\footnotetext{
${ }^{1}$ The offenses provided by the State of Kelantan legislature are fewer than other states in Malaysia such as Pulau Pinang have provided 26 offenses in the Pulau Pinang Islamic Law Enactment; The State of Johor Administrative has allocated 44 sections; The administrative State of Pahang has allocated 54 sections.

${ }^{2}$ However, other states in Malaysia have been heavily punished by the allocation of the Kelantan Council of Religion and Malay Custom Enactment. e.g. the State of Perlis and the State of Perak, which provides of an affence punishable with imprisonment not exceeding 1 year. See Section 117 of the Administration of Islamic Law Enactment of Perlis no. 3 of 1964; see also Section 155, 181 of the Perak Islamic Law Enactment No. 11 of 1965.
} 
after the revision of Act 355 and in period of 19 years after the previous enactment, the state of Kelantan have legislated the Shariah Criminal Code 1985. The code have provided 27 offences which indorsing an increased of 9 crimes compared to the previous statute. Four of the crimes penalty have involved whipping punishment between three to six strokes, that is for the offence of adultery (zina), an act preparatory to the commission of zina, liwat and intoxicating drinks.

In line with the development, the Kelantan government has amended Syariah Criminal Procedure Enactment 1983 to ensure justice and fairness (M. S. A. Othman, 1996). However, the 1983 Enactment only contains 207 section that involve prisonment and fine without whipping prosedure (Ibrahim, 1999). Therefore in Kelantan, there are the Shariah Criminal Code Enactment 1985 as well as the Shariah Court Civil Procedure Enactment. The separation of the codes were projected so that the administration and the law are seen more orderly, comprehensive and thorough (Majid, 1997). However, the enactment still does not meet the provisions of the real Islamic criminal law (Ibrahim, 1999).

Correspond with this amendment, the Kelantan State legislature in 1987 has updating the Shariah Criminal Procedure which approved whipping rules punishment and became the earliest State to provide the ruling. Meanwhile in other states, the progress is left ten years behind as Federal Territories only provide in the Shariah Criminal Procedure (Federal Territories) Act in 1997 (Section 125, 126). In the Kelantan Shariah Criminal Procedure Enactment 2002, the whipping rules was initially provided (Enactment No. 8 of 2002). The details procedure in applying whipping is provided in Section 125 and 126 of The Enactment. Section 125 (2) provided that the whipping rod, excluding its holder, shall be of the same type and make either from rattan or small branch of a tree without segment or joint and its length not more than 1.22 meters and its thickness not more than 1.25 centimeters. Meanwhile the following provisions shall be followed when executing the sentence of whipping, that is (Sub-section 3):

a) before execution of the sentence, the offender shall be examined by a Government Medical Officer to certify that the offender is in a fit state of health to undergo the sentence;

b) if the offender is pregnant, the execution shall be postponed until the end of two months after delivery or miscarriage, as the case may be;

c) the sentence shall be executed before a Government Medical Officer in such place as the Court may direct or in a place fixed by the State Government for the purpose;

d) the person appointed to execute the sentence shall be an "adil" and mature person;

e) the person shall use the whipping rod with average force without lifting his hand over his head so that the offender's skin is not cut;

f) after inflicting a stroke, he shall lift the rod upward and not pull it;

g) whipping may be inflicted on all parts of the body except the face, head, stomach, chest or private parts;

h) the offender shall wear clothes according to Hukum Syarak;

i) if the offender is male the whipping shall be inflicted in a standing position, and if a female, in a sitting position;

j) if during the execution of the whipping the Government Medical Officer certifies that the offender can no longer receive the strokes, the whipping shall be postponed until the Medical Officer certifies that the offender is fit to undergo the balance of the sentence. 
In the case where the offender is sentenced to whipping only, then he shall be dealt with as if he is sentenced to imprisonment until the sentence is executed. If the Government Medical Officer certifies that the offender, due to old age (fifty years and above), illness or any other reason is unable to undergo the whipping sentence wholly or partly, the case shall be referred to the Court which may order the execution of the sentence in a manner as it thinks reasonable (Subsection 4 and 5).

Pertaining to time of executing sentence of whipping, Section 126 (1) provided that when the accused is sentenced to whipping in addition to imprisonment, the whipping shall not be inflicted if an appeal is made and until the sentence is confirmed by the appropriate appeal Court. However the whipping shall be inflicted as soon as practicable and in case of an appeal, as soon as practicable after the receipt of the order of the appropriate appeal Court confirming the sentence (Sub-section 2).

\section{The Whipping Rules Punishment Under the Kelantan Criminal Code}

There are two model of criminal code in the State of Kelantan, that is model 1985 and model 1993. M. S. A. Othman (2000) concluded that the form of whipping law in the Enactment 1985 is in the jurisdiction of takzir. The finding was highlighted based on its provision that was underlined by restriction given by the 355 Act which is in line with the provision of the Ninth Schedule of the Federal Constitution (Yaacob, 1996). However, the scale in assessing the shariah punishment is differ to the shariah offences. According to Mohamed (1993), the offences in the Shariah Criminal Code (EKJS) of Kelantan 1985 cannot be generalised as the whole takzir. Part of the offences are hudud that is an act of violating the prohibition of shariah law that were reveal in the Quran and Hadith.

Six offences punishable with whipping under the Shariah Criminal Code of Kelantan 1985 that are offenses related to zina (Section 11), an act preparatory to the commission of zina (Section 12), liwat (Section 16), intoxicating drinks (Section 25), abetment (Section 29) and attempts (Section 30). In applying whipping sentence, the Enactment clearly states that the law does not liable to the punishment of had, but on conviction, the offender shall be liable to a maximum of six strokes of whipping despite of imprisonments and fines. Therefore, the penalties fall under the jurisdiction of takzir. The maximum whipping penalty in the Enactment is provided for zina, liwat, intoxicating drinks and abetment (six stroke). Meanwhile for an act of preparatory to the commission of zina and attempts, the whipping penalty is not exceeding three strokes or one-half of the punishment provided for the offence. The whipping penalty in the Enactment is illustrated in the Table 1 below: 
INTERNATIONAL JOURNAL OF ACADEMIC RESEARCH IN BUSINESS AND SOCIAL SCIENCES Vol. 8, No. 9, Sept. 2018, E-ISSN: 2222-6990 @ 2018 HRMARS

Table 1: The whipping punishment in the Kelantan Shariah Criminal Code 1985

\begin{tabular}{|c|c|c|c|c|}
\hline No & Offences & Offences Type & Section & Number of Stroke \\
\hline 1 & Zina & Hudud & 11 & whipping no exceeding 6 strokes. \\
\hline 2 & $\begin{array}{l}\text { An act } \\
\text { preparatory to } \\
\text { the commission } \\
\text { of zina }\end{array}$ & Takzir & 12 & $\begin{array}{l}\text { whipping for a term not exceeding } 3 \\
\text { strokes. }\end{array}$ \\
\hline 3 & Liwat & Takzir & 14 & whipping not exceeding 6 strokes. \\
\hline 4 & $\begin{array}{l}\text { Intoxicating } \\
\text { drinks }\end{array}$ & Hudud & 25 & whipping not exceeding 6 strokes. \\
\hline 5 & Abetment & Takzir & 29 & $\begin{array}{l}\text { shall be punished with the same } \\
\text { punishment as if he had committed the } \\
\text { said offence }\end{array}$ \\
\hline 6 & Attempts & Takzir & 30 & $\begin{array}{l}\text { punishment not exceeding one-half of } \\
\text { the punishment provided for the } \\
\text { offence }\end{array}$ \\
\hline
\end{tabular}

Practically, in a serious case such as pertaining to hudud offenses, the Shariah Court choose to punish offender by imprisonment or whipping so the penalty imposed is seem to be maximum. For instance in the Kelantan Shariah Prosecutor vs Yusundy Josan (1989), the Kelantan High Court sentenced for an offence of intoxicating drinks to imprisonment for a term of 6 months and whipping to 6 strokes (13/89; see too http://www.esyariah.gov.my. Accessed by 27 Julai 2016).

Then in 1993, the State of Kelantan have strengthened the shariah criminal code by endorsing the Shariah Criminal Code II which provides for a wider jurisdiction in applying the Islamic criminal law. The code contains provisions on qisas, hudud and takzir, which involve offences and penalties. The new code shows the expansion of Islamic punishment in the original form which contained a whipping penalty of up to a hundred strokes. In brief, the summary of the whipping penalty in the Code II of 1993 (amendment 2015) is illustrated in the Table 2 below:

Table 2: The whipping punishment in the Kelantan Shariah Criminal Code 1993 (2015)

\begin{tabular}{|c|l|c|c|l|}
\hline No & \multicolumn{1}{|c|}{ Offences } & Offences Type & Section & \multicolumn{1}{|c|}{ Number of Stroke } \\
\hline 1 & $\begin{array}{l}\text { Adultery (ghairu } \\
\text { mohsan) }\end{array}$ & Hudud & 13 & $\begin{array}{l}\text { the offender shall be punished with } \\
\text { whipping of 100 lashes }\end{array}$ \\
\hline 2 & Sodomy & Takzir & 15 & $\begin{array}{l}\text { shall be punished with the same } \\
\text { punishment as prescribed for adultery }\end{array}$ \\
\hline 3 & Qazaf & Hudud & 18 & $\begin{array}{l}\text { shall be punished with whipping of } 80 \\
\text { lashes }\end{array}$ \\
\hline 4 & Syurb & Hudud & 22 & $\begin{array}{l}\text { shall be punished with whipping of not } \\
\text { more than } 80 \text { lashes and not less than } \\
40 \text { lashes }\end{array}$ \\
\hline
\end{tabular}


In executing of the above whipping punishment, Section 53 of the Code II of 1993 (amendment 2015) have provided that the punishment shall be carried out in accordance with the provisions in sections 125 and section 126 of Syariah Criminal Procedure Enactment 2002. With regards to pregnant female offender, the punishment of whipping shall not be executed on her until she has delivered her child, and thereafter become clean of blood and is fit again to undergo the punishment without hazard (Section 55).

However till recent development, an enforcement of the Shariah Criminal Code II of 1993 (Amendment 2015) is still not applicable as the provisions is in conflicting with the Federal Constitution as well as other Federal Statutes such as the 355 Act and the Penal Code. Therefore, the provision is considered ultra-vires with the Federal Law and hence could not be enforce by the State Government. Therefore, the applicable law is the Shariah Criminal Code of 1985 which involve the scope of whipping punishment in takzir.

\section{Analysis on Whipping Penalty in the State of Kelantan}

As previously mentioned, the State of Kelantan is the earliest state in Malaysia which introduced the Whipping Rules in 1987. The rules was aimed at harmonizing in executing punishment that is to be consistent with the maqasid of syariah. ${ }^{74}$ This is because punishment in Islam is not just to punish, but to educate people. Therefore the execution should be made in public and open.

Therefore the lashes in Islam are simple. The principle was followed by the State of Kelantan which is provided in the law to use a whip device of a cane measuring one meter long and a centimeter diameter (Section 35, Rules 2, Whipping Rules 1987). Some improvement is done in year 2002 to use whipping rod, excluding its holder, shall be of the same type and make either from rattan or small branch of a tree without segment or joint and its length not more than 1.22 meters and its thickness not more than 1.25 centimeters (Enactment of 2002). The guidence of whipping rules in applying the law have shown that the implementation of legal action in Islam requires thoroughness and full of considerations. The punishment shall not be executed unless the offender is in a good condition as provided in the whipping rules of 1987 and the Shariah Criminal Procedure Code 2002 whereby the health of the offender shall be certified by the Government Medical Officer that he is fit to undergo such punishment (Section 35, Rule 11, Whipping Rules 1987; Section 125 (3a) Enactment No. 8 Syariah Procedure Criminal Code Enactment 2002).

The Shariah Court (Section 35, Rule 11, Whipping Rules 1987) have jurisdiction in determining an appropriate place and time for the execution of whipping punishment (Section 125 (3a) Enactment No. 8 Syariah Criminal Procedure Enactment 2002). According to Ismail (2004), the shariah punishment in Kelantan is only carried out at Pengkalan Chepa and the execution of the penalty should be witnessed by at least of 4 Muslim (Section 35, Rule 4, Whipping Rules 1987). However, in the Shariah Criminal Procedure Code of 2002, there is an additional phrase in this regard that the State Legislature has a power to determine an appropriate place including carrying whipping punishment in public. This policy must be exercised before a whipping punishment is executed on a offenders (Mujahid, 2017). Therefore, there is no provision for witnesses in the Shariah Criminal Procedure Code Enactment 2002 because it may involve more if the "place of punishment" is not just in prison (Section 125 (c) Enactment No. 8 Syariah Criminal Procedure Enactment 2002). 
The requirement of whipping punishment in public is part of law suit in the hudud law. Based on the Shariah Criminal Prcedure Enactment 2002, Che Ibrahim Mohamed who was the former Kota Bharu Shariah Court Judge in opinion that this is not impossible. The general proviso of the Section 125 and 126 of the Shariah Criminal Procedure Enactment 2002 have allowed the court to direct the execution of whipping in a place that designated by the State Government and whipped by an appointed officer (Enactment No. 8 2002, Enactment Syariah Criminal Procedure 2002). The execution meet the requirement of the State Legislative Assembly of Kelantan when they passed the bill in 2002 as well as during the amendment in 2017, to be carried out in the public (https://www.malaysiakini.com/news/388282). However, the Amendment 2017 Enactment has not enforceable because has not yet been gazetted by the Kelantan authorities.

There were three cases of shariah whipping punishment that have been implemented in public by the Tawau Syariah Court in 2014 and 2016 (Borneo Post July 15, 2017). The progress have shown that the practise was constitutional and declined the view that it is unconstitutional. As long as the punishment are done under the jurisdiction of the Shariah Court based on legal authority by the particular statute, it is legal and authorised. Hence, the view of Nizam Bashir that whipping punishment in public was considered unconstitutional except in prisons is considered unjustified (Mujahid, 2017).

In term part of the body to be whipped, the Whipping Rules 1987 has provided that face, head, chest and genitals cannot be whipped during the punishment (Section 35, Rule 7, Whipping Rules 1987). In terms of Jurisprudence, the Hanafi, Shafi'i and Hanbali schools allow whipping in any part of body other than the head and genitalia for offence of hudud (Al-Kasani, 1986); (Al-Sharbini, 1994). To reduce the pain, the should not to strike on the same place. While the Maliki School on views that whipping should be imposed on the back of the offender's body for hudud offences (Farhun \& ibn Muhammad, 1884).

Both ruling either shariah or civil law in Malaysia have emphasized prudence and respect in executing the whipping. The Shariah Criminal Procedure Enactment 2002 provides that whipping should be done in a modest manner, not lifting the cane above the head level, performed consecutively and not exceeding the number of court decisions (Section 35, Rule $8(1,2,3)$, Whipping Rules 1987). In addition, rattan should be lifted and not pulled after a stroke is carried out on the offender (Section 125 (f) Enactment No. 8 Syariah Criminal Procedure Enactment 2002). The rule and procedures were outlined vigilantly so that the strokes do not hurt the offender's skin. Meanwhile, the shariah whipping procedure is slightly different from a civil whipping that can normally cause skin injuries after a whipping is performed. The goal required in the execution of the whipping as claimed by Al-Sabuni (1992) and Ibn Rushd (2003) is that such punishments can cause pain but do not hurt or tear the skin. In this case, the whipping rules allow an offender to wear thin cloth so that the lashes imposed does not cause great pain to offender. The general guidelines of the offender attire has found to be incompatible with the views of Imam Malik, Syafi i and Abu Hanifah. They have viewed that male offender for all types of hudud offences should be whipped in the case of not wearing clothes except merely covering private parts (aurah) only. However, for women, it is suitable with their restraints are not wearing thin clothes (Al-Sharbini, 1994). Even Syafi'i and Hanbali suggested that women's clothes be tied up so as not to be lifted when the strokes were carried out (Hashim, 2014). 
In terms of body position, the Whipping Rules 1987 provides that all offenders during the whipping shall be standing and wearing thin cloth covering the parts of his body according to hukum syarak (Section 35, Rule 9, The Whipping Rules 1987, Syariah Criminal Code Enactment 1985). This policy does not differentiate between male and female offenders. However, this rules has been amended in the Shariah Criminal Procedure Enactment of 2002 which differentiates between the position of male and female offenders; the male offender shall be standing and the female offender shall be sit down (Section 125 (i) Shariah Criminal Procedure Enactment 2002). Standing position is meant to allow strokes to be imposed on the whole body of the offender (Ibn'Abidin, 1994). Many scholars believe that the offender does not need to tie up hands or feet when the whipping execution except for offenders who refuse to obey sitting or standing instructions (Rusyd, 2009). Therefore, regulation on cloth and standing or sitting position during execution is beneficial (mas/ahah) which have been provided in the Syariah Criminal Procedure Enactment 2002. However, the Shariah Criminal Procedure Enactment 2002 did not provide the condition of offenders who refused to obey standing or sitting orders when the sentence whipping were carried out. The study found that there are provisions that have not included in the Shariah Criminal Procedure Enactment 2002 such as about point of time in the punishment. This is important if the punishment is executed publicly, the time either morning, evening or night have significant influence to the offenders in getting the punishment (Al-Dasuqi, 2003) which will cause additional pain or not. After all, the execution of whipping should determine the maslahat to the offender in receiving the punishment.

\section{CONCLUSION}

The whipping punishment under shariah is imposed on criminal offenders that is under hudud offences and takzir. The sanction is provided by the Shariah and its implementation is compulsory. Under hudud, punishment of whipping is provided towards illegal intercourse among bachelors (ghayr muhsan), sexual defamatory (qazaf), drinking alcohol (syurb), and gambling (maysir). While under takzir, any hudud offences that does not have sufficient evidence can be sanctioned by whipping. However, the number of stroke in takzir is flexible than the punishment in hudud. Whipping shall be temperate, moderate and non-cracking, distributed, otherwise than the face, head and fatal places, by a moderate whip, and any other similar tool may be used. The Shariah law also does not distinguish between male and female offenders in imposing this sentence as all offenders shall suffer the same modes of sentencing when they have committed any crime.

The study also found that the sentence of whipping in the Kelantan Shariah Court has been systematically developed. However, the scope of the development was limited because of the restriction by the Federal Law, that is Federal Constitution as well as the Shariah Criminal Jurisdiction 1965 (Amendment) Act 1984 (Act 355). Therefore, it left the jurisdiction under the scope of takzir punishment. Four of the crimes penalty that involve whipping punishment in the Kelantan Criminal Code the offence of adultery (zina), an act preparatory to the commission of zina, liwat and intoxicating drinks. In 2002, the sentences whipping procedure through the Shariah Criminal Procedure Enactment 2002 have provided further improvements to the provisions of the Whipping Rules 1987 that the sanction can be conducted in public for public witnesses. However, proper procedure should be abide such as on proper time, in proper place as well as using proper tool to prevent torture to offenders as well as to ensure the sanction will be held in smoothly. 
INTERNATIONAL JOURNAL OF ACADEMIC RESEARCH IN BUSINESS AND SOCIAL SCIENCES

Vol. 8, No. 9, Sept. 2018, E-ISSN: 2222-6990 (C) 2018 HRMARS

\section{Acknowledgments}

This research was funded by the University Sains Malaysia Fellowship that lies under the Institute of Postgraduate Studies.

\section{Reference}

Syariah Criminal Procedure Enactment Kelantan, (2002).

Abu Daud. (2009). Sunan Abi Daud. Damsyik: Dar al-Risalah al-،Alamiyyah.

Ahmad, A. S. (1989). Serangkai warisan sejarah. Kuala Lumpur: Dewan Bahasa dan Pustaka.

Al-Bukhari. (1400 H). Al-Jami ،al-Sahih. Kaherah: Al-Matba،ah al-Salafiyyah wa Maktabuha.

Al-Dasuqi, S. a.-D. (2003). Hashiyah al-Dasuqiala al-Sharh al-Kabir. Qahirah: Dar Ihya'al-Kutub alArabiyyah.

Al-Kasani, A. (1986). Bada'i al-Sana'i fi Tartib al-Shara'i. Beirut: Dar al-Kutub al-Ilmiyyah.

Al-Mawardi. (1966). Al-Ahkam al-Sultaniyyah. Mesir: Matba‘ah Mustafa al-Babi al-Halabi.

Al-Ramli, S. u.-D. M. b. A. a.-A. A. b. H. b. S. a.-D. (1968). Nihayat ila Syarh al-Minhaj. Egypt: Maktabah Mustafa al-Halabi.

Al-Sabuni, M. A. (1992). Safwah al-tafasir. Beirut: Mu'assasah Manahil al-Irfan.

Al-Sharbini, A.-K. (1994). Mughni al-Muhtaj. Beirut: Dar al-Fikr.

Al-Tirmizi, A. I. (2000). Jami Al-Tirmizi. Arab Saudi: Wizarah Syuun al-Islamiyyah wal Auuqaf wal Dakwah wal Irsyad.

Audah, A. Q. (1963). Al-Tasyri Al-Jina-I Al-Islami Muqaran Bin Al-Qonun Al-Wadh'I: Misra: Maktabah Dar Al-Arubah.

Aziz, S. A. (2007). Islamic criminal law in the Malaysian federal structure: A constitutional perspective. IIUM Law Journal, 15(1), 101-120.

Farhun, I., \& ibn Muhammad, I. (1884). Tabsirat al-hukkam. Cairo: al-Matba'ah al-Bahiyyah H, 1302, 249.

Hashim, A. M. (2014). Kaedah Pelaksanaan Hukuman Sebat Di Dalam Islam. Jurnal Syariah, 8(2), 114.

https://www.malaysiakini.com/news/388282. "Kelantan lulus rang undang-undang sebat di khalayak ramai". Accessed 12 July 2018.

Ibn Majah, M. b. Y. (2007). Sunan Ibn Majah. Arabic-English by Nasiruddin al-Khattab Translation. Saudi Arabia: Darussalam.

Ibn Rushd. (2003). Bidayat al-mujtahid wa nihayat al-muqtasid. Lubnan: Dar al-Kotob al-IImiyah.

Ibn'Abidin, M. A. (1994). Radd al-Mukhtar 'ala al-Durr al-Mukhtar Sharh Tanwir al-Absar, vol. 3. Beirut: Dar al-Kutub al-'llmiyyah.

Ibrahim, A. (1994). Explanation of The Syariah Criminal Code, The Implementation of Hudud Law In Kelantan. Kota Bharu: Telda Corporation Sdn. Bhd.

Ibrahim, A. (1999). Perkembangan Undang-undang Perlembagaan Persekutuan. Kuala Lumpur: Dewan Bahasa dan Pustaka.

Ismail, S. Z. (2004). Pengalaman Negeri Kelantan Dalam Melaksanakan Hukuman Sebat Rotan Terhadap Kesalahan J enayah Syariah. Jurnal Syariah, 12(1), 101-110. 
INTERNATIONAL JOURNAL OF ACADEMIC RESEARCH IN BUSINESS AND SOCIAL SCIENCES

Vol. 8, No. 9, Sept. 2018, E-ISSN: 2222-6990 @ 2018 HRMARS

Ismail, S. Z. (2014). Hudud Dan Undang-Undang Jenayah Syariah Dalam Kerangka Perlembagaan Dan Sistem Perundangan "Dualisme": Komitmen Pelaksanaan Ke Arah Membendung Jenayah Di Malaysia. Jurnal Syariah, 22(2), 193-212.

Kamaruddin, A. H. H. (1989). Criminal law (Islamic law). Petaling Jaya: Al-Rahmaniah.

Majid, M. Z. b. A. (1997). Introduction of Islamic Law in Malaysia. Kuala Lumpur: University Malaya.

Mohamed, M. (1993). Undang-undang Jenayah Islam Mengenai Jenayah Qisas Bunuh. Kuala Lumpur: Dewan Pustaka Fajar [dan] Persatuan "Ulama`Malaysia.

Mujahid, N. (2017). Sebatan di Khalayak Secara Mandatori Boleh Menjadi Trend Nasional. Retrieved from Penang:

Othman, M. S. A. (1996). Institusi pentadbiran undang-undang \& kehakiman Islam: Dewan Bahasa dan Pustaka.

Othman, M. S. A. (2000). Pendekatan Siyasah Syar iyyah Dalam Pentadbiran Negara. Jurnal Undangundang IKIM, 4(1), 57-89.

Othman, Y. B., Joni, E. K. E., \& Mahat, I. R. b. (2011). A comparative study on whipping as punishment for muslim women offenders. Paper presented at the Seminar Perundangan Islam dalam Masyarakat Kontemporari ISLAC 2011.

Qudāmah, M. A. b. A. I. (1980). al-Mughnī: Maktabh al-Jumhuriyah al-'Arabiyah.

Rusyd, I. (2009). Bidayah al-Mujtahid wa Nihayah al-Muqtasid. Beirut: Dar al-Fikr, j, 2.

Sabah Syariah Court records 3 open whipping sentences. (2017). Borneo Post.

Su-Ming, C. (1965). Kelantan and Trengganu, 1909-1939. Journal of the Malaysian Branch of the Royal Asiatic Society, 38(1 (207), 159-198.

Yaacob, A. M. (1996). Siyasah Syar'iyyah Dalam Pentadbiran dan Perundangan. Kuala Lumpur: IKIM.

Zaydan, A. A. K. (1993). Al-Mufassal Fi Ahkam al-Mar'ah (Vol. 4). Beirut: Muassasat al-Risalah. 